\title{
Employment around first birth in two adverse institutional settings: Evidence from Italy and Poland
}

\section{Erwerbstätigkeit im Umfeld der ersten Geburt in zwei gegensätzlichen institutionellen Rahmungen: Ergebnisse aus Italien und Polen}

\begin{abstract}
:
This paper analyses women's employment behaviour around first birth in Italy and Poland. These two countries have much in common as far as their cultural and institutional frameworks are concerned. However, they also display key differences that allow us to better investigate how the country-specific factors mediate women's employment behaviour around the first birth. Our findings reveal substantial differences in women's behaviour across educational groups and between the two countries. We conclude that conditions for combining work and family, although important, are not the only determinants of women's fertility and employment decisions, and that other country-specific factors are also highly influential.
\end{abstract}

Key words: Women's employment, first childbirth, Italy, Poland, event history analysis

\begin{abstract}
Zusammenfassung:
In diesem Artikel wird das Erwerbsverhalten von Frauen in Italien und Polen im Umfeld der Geburt des ersten Kindes analysiert. Diese beiden Länder haben hinsichtlich der kulturellen und institutionellen Rahmenbedingungen viel gemeinsam. Sie weisen jedoch auch zentrale Unterschiede auf, die es uns erlauben, genauer zu untersuchen wie die länderspezifischen Faktoren das Erwerbsverhalten von Frauen im Umfeld der Erstgeburt beeinflussen. Unsere Ergebnisse zeigen, dass substanzielle Unterschiede im Verhalten über Bildungsgruppen hinweg und zwischen den beiden Ländern bestehen. Wir kommen zu dem Schluss, dass die Bedingungen der Vereinbarkeit von Arbeit und Familie zwar wichtig, aber nicht die einzigen Determinanten für die Entscheidungen der Frauen hinsichtlich der Fertilität und der Erwerbstätigkeit sind. Andere länderspezifische Faktoren sind dabei ebenfalls sehr einflussreich.
\end{abstract}

Schlagwörter: Frauenerwerbstätigkeit, Erstgeburt, Italien, Polen, Ereigniszeitanalyse

\section{Introduction}

The labour market participation rates of women are lower than those of men everywhere in Europe. This fact has often been attributed to the disproportionate participation of 
women and men in childbearing and childrearing. While the gender gap in employment is country-specific, it is often larger in countries with lower fertility than it is in countries with higher birth rates. The economic theory of fertility and of women's labour supply attributes this phenomenon to cross-country differences in the opportunity costs of childbearing, such as the income lost during the non-participation period, but also future earnings foregone due to non-accumulation and depreciation of human capital (Gustafsson 2001; Walker 1995). These costs are larger in countries with rigid labour markets and a pronounced insider-outsider divide, and in countries that lack safety nets and family policies oriented towards supporting the successful balancing of motherhood and paid work (Esping-Andersen 1999; Matysiak/Vignoli 2008).

Recent micro-level research has, however, challenged conventional wisdom on fertility and women's labour supply by showing that, in some countries, employed women are more likely to give birth to a child, even if there are strong institutional barriers to combining work and family. This evidence mainly comes from the post-socialist countries (Robert/Bukodi 2005; Matysiak 2009a; see also Kreyenfeld 2010 for a more general discussion), and suggests that, in some country contexts, women's employment may function as a precondition to childbearing. These findings call for a deeper investigation into how the country-specific factors mediate the interrelationship between childbearing and women's labour supply.

Comparing highly similar countries that also display some specific and well-recognised differences has recently been recommended by Neyer and Andersson (2008) as a meaningful strategy for analysing the influence of country-specific factors on the studied phenomena. In this paper, we follow this approach by comparing Italy and Poland. On the one hand, these two low-fertility countries have much in common as far as their cultural and institutional frameworks are concerned. Religiosity, strong family ties, the fundamental importance of marriage, rigid labour markets, as well as institutional lags that impede the reconciliation of work and family are perhaps the most important factors uniting Italy and Poland. Both countries are also characterised by low levels of employment among women. However, the labour force participation of women aged 25 to 44 is much higher in Poland than in Italy, which might be seen as an indicator of the greater determination of Polish women to participate in economic activity.

In our study, we focus on women's employment at a certain stage in a woman's life course; namely, around the first birth. We find that particular stage in a woman's life course to be important for two reasons. First, strong work-family tensions may lead to fertility postponement, and, as a result, to smaller family size or even childlessness. Second, difficulties with (re-)entering the labour market after first childbirth may seriously discourage further childbearing. The paper thus sets out to investigate how employment influences the transition to motherhood in the two analysed countries, as well as how having a small child influences a woman's decision to (re-)enter employment. Our study provides further evidence that conditions for combining work and family, although important, are not the only determinant of women's fertility and employment decisions, as other country-specific factors are also highly influential.

The paper is structured as follows: The next section describes the context in which Italian and Polish women make their employment and reproductive choices. The macrolevel developments in first-order fertility and women's labour supply in the two countries 
are presented in the next step. In the following section, we present the results of our empirical investigation of employment around first birth in Italy and Poland. The paper concludes with a summary and a discussion of the findings.

\section{Italian and Polish context}

Italy and Poland represent an opportunity for comparison that has, as yet, been largely unexplored. There are strong similarities between these two societies that set them apart from much of the rest of Europe, including the still-low rates of cohabitation, non-marital childbearing and marital disruption (Hantrais 2005). The delayed diffusion of new family behaviour is often linked to the pressure imposed by the Catholic values prevalent in the two countries (De Rose et al. 2008; Kotowska et al. 2008). Only recently have the countries started to experience a slight weakening of ties with the Church. This process is particularly visible among the younger generations, and is manifested in an increase in separation and divorce (Vignoli/Ferro 2009), as well as in cohabitation (Matysiak 2009b).

Additionally, both societies are characterised by strong family and intergenerational ties (Dalla Zuanna/Micheli 2004; Mai et al. 2008; Stankuniene/Maslaukaite, 2008). Parents support their children after leaving the parental home by helping them to establish an independent household and by later providing care for their children. In turn, they receive financial and emotional support in old age (De Rose et al. 2008).

Strong involvement of family members in providing care and support to each other, as well as the commonly shared conviction that families are the most relevant source of social aid, have been accompanied by very little state intervention. Weak public support provided to working parents leads to strong conflicts between work and family that seem to be particularly pronounced in Poland. The availability of public childcare for the youngest children, aged $0-2$, is very low in both countries. In addition, the supply of childcare facilities for pre-schoolers is far from sufficient in Poland (see Table 1). Instead of using public childcare facilities, mothers can make use of maternity and parental leave entitlements. In both countries, these entitlements are offered to all working mothers irrespective of their work record, but Poland is much more generous than Italy in terms of leave duration. In Italy, a five-month maternity leave is followed by an optional parental leave of six months, which gives mothers the opportunity to stay at home with the child for up to 11 months without forfeiting their work contract. In Poland, by contrast, a mother can stay home for almost 3.5 years by opting for a three-year parental leave after taking a 16 -week maternity leave ${ }^{1}$. Furthermore, if she delivers another child during that time the mother becomes entitled to another maternity leave as well as parental leave on equal terms with a working woman. In both countries, parental leave can be taken by both the mother and the father until the child is eight years old. In the great majority of cases, however, it is taken by mothers directly after the maternity leave. While the financial compensation during maternity leaves is rather high ( $80 \%$ in Italy and $100 \%$ in Poland),

1 These regulations were in force until the end of 2007. Since the beginning of 2008, some changes have been introduced into the parental leave system. We do not refer to them in this paper because the data we use in our empirical investigation was collected in 2006. 
the parental leave benefits are rather low (see Table 1). Moreover, in Poland, only mothers who meet certain income criteria are entitled to a parental leave benefit. For those mothers who decide to work, family members constitute an important source of childcare. The Eurostat survey "Reconciliation between work and family life" has shown that around $40 \%$ of working mothers receive help from other family members ${ }^{2}$.

The work-family tensions are further exacerbated by rigid working hours, strong barriers to labour market entry, as well as the relatively high degree of uncertainty of employment contracts. These are reflected in low numbers of part-time jobs, high unemployment rates, and the prevalence of temporary contracts among the youth, relative to many other European countries (Table 1). Again, the rigidity of working hours, as well as job instability, seems to be higher in Poland than in Italy.

Table 1: $\quad$ Contextual indicators, Italy and Poland.

\begin{tabular}{|c|c|c|}
\hline & Italy & Poland \\
\hline \multicolumn{3}{|l|}{ Childcare provision $^{\text {a) }}$} \\
\hline children aged 0-2 & $7.4 \%$ & $2.4 \%$ \\
\hline children aged 3-6 & $95 \%$ & $61.9 \%$ \\
\hline \multicolumn{3}{|l|}{ Parental leave ${ }^{\text {b) }}$} \\
\hline Duration & 6 months & 36 months \\
\hline Benefit & $\begin{array}{l}30 \% \text { of monthly earnings in } \\
\text { private sector, and } 80-100 \% \\
\text { in public sector }\end{array}$ & $\begin{array}{c}\text { means-tested, flat rate at } \\
\text { around } 15 \% \text { of the average } \\
\text { wage in the national economy }\end{array}$ \\
\hline $\begin{array}{l}\text { Proportion of working mothers with children up to } \\
\text { age } 14 \text { who receive childcare support from kin }{ }^{\text {c) }}\end{array}$ & $40 \%$ & $42 \%$ \\
\hline \multicolumn{3}{|l|}{ Labour market structures ${ }^{d)}$} \\
\hline $\begin{array}{l}\text { \% part-time employed among employed, persons } \\
\text { aged } 25-49 \text { in } 2006\end{array}$ & 27.9 & 9.3 \\
\hline $\begin{array}{l}\text { unemployment rate among the youth (aged 15-24) in } \\
2006\end{array}$ & 21.6 & 29.8 \\
\hline $\begin{array}{l}\text { \% temporarily employed among employed, persons } \\
\text { aged } 15-24 \text { in } 2006\end{array}$ & 38.0 & 59.0 \\
\hline
\end{tabular}

Source: a), b) - Italy: Neyer (2003) and De Rose et al. (2008), Poland: Matysiak (2008, pp. 156-157), c) - Eurostat Statistics Database (data from the "Reconciliation between work and family" survey 2005), d) - Eurostat Statistics Database (Labor Force Survey data).

Finally, the attitudes toward working mothers in both of the analysed countries are very traditional, and the gender division of tasks is highly asymmetric (e.g., Mencarini/Tanturri 2006; Muszyńska 2007; Philipov 2008). The viewpoint that women should withdraw from the labour market when children are young also prevails in Poland, despite the fact that the state ideology strongly encouraged the labour force participation of women during the socialist period. Even during that era, women were perceived to be the main homemakers and care providers, while also being expected to work in the market (Siemieńska 1997).

2 For more information on the survey see Eurostat (2005). 


\section{Macro-level developments in first-order fertility and women's labour supply}

Despite the strong position of the Catholic Church, the attachment to the family, and the prevalence of traditional family forms, Italy and Poland have experienced a marked decline in childbearing, and are currently among the European countries with the lowest fertility levels. Younger generations increasingly opt for late entry to parenthood, and the proportion of childless adults has increased substantially in both countries.

The process of fertility postponement is illustrated in Figures 1a-b, which display the cohort first birth age-specific fertility rates. Note that the time series for Italy are shorter than for Poland because of the data limitations. In Italy, the postponement is observed starting with the cohorts born in the mid-1960s. Figure 1a clearly shows the decline in first birth rates at ages 20-25, and an increase thereafter. In Poland, the same processes started later, with cohorts born in the 1970s (Figure 1b). As a result of these changes, the mean age at first delivery in Italy increased from 25 in the early 1970s, to 29 in 2007. In Poland, it rose from 23.3 in 1989 to 25.8 in 2007.

Women not only delay the transition to motherhood; they also increasingly remain childless. In Italy, the proportion of childless women rose from 10\% among the 1955 cohort, to $20 \%$ among the 1965 cohort (Figure 2). In Poland, this process started slightly later, with the percentage of women who had no children jumping five percentage points from 1960 to 1965 cohort, to $15.4 \%$ for the latter cohort.

Figure 1: First birth age-specific fertility rates. (a) Birth cohorts 1950, 1960, 1965, 1970, 1975 and 1980, Italy. (b) Birth cohorts 1960, 1965, 1970, 1975, 1980, and 1985, Poland.

a) Italy

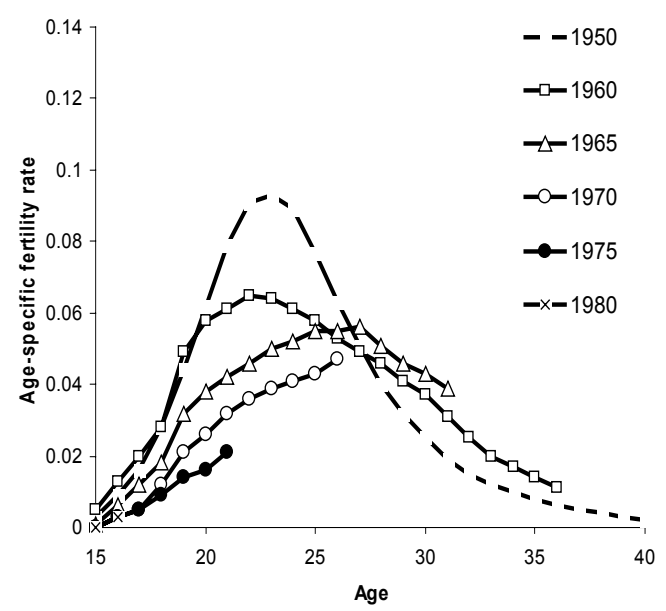

b) Poland

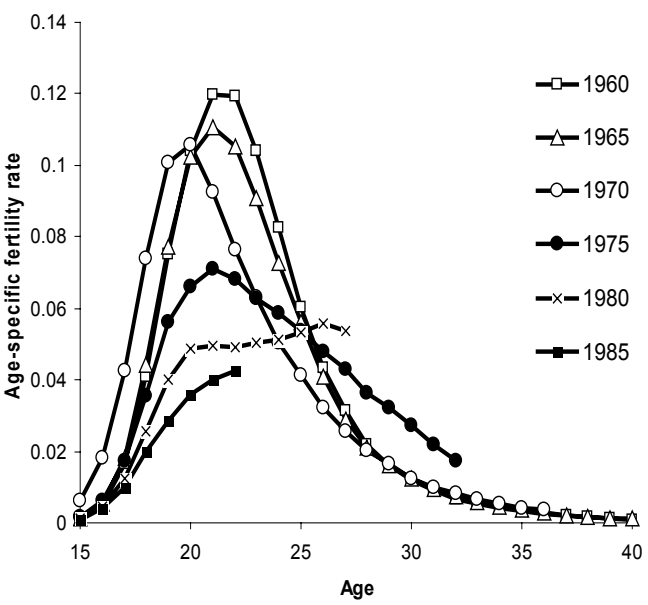

Source: Observatoire Démographique Européen and computations by Krzystof Tymicki for Poland for the years 2004-2007, based on the Polish Birth Register. 
Figure 2: First birth total cohort fertility rate (CTFR1), birth cohorts 1922-1967 for Italy, and 1938-1967 for Poland

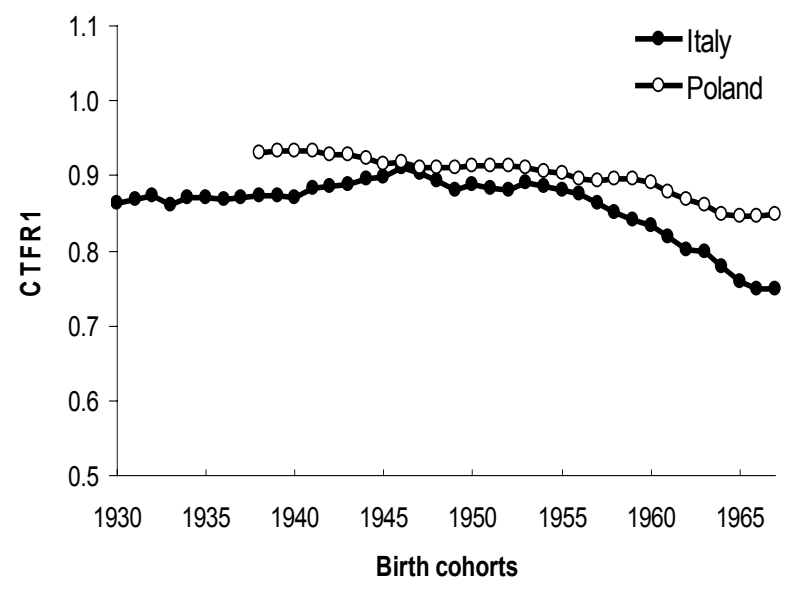

Source: Observatoire Démographique Européen and additionally De Rose et al. (2008) for Italy, cohorts 1960-1967, and computations by Krzystof Tymicki for Poland for the years 2004-2007, based on the Polish Birth Register.

The massive fertility postponement and increasing childlessness observed in the two countries have often been linked in the literature to the strong tensions between fertility and women's work. Interestingly, despite the fact that the conditions for combining work and family are generally considered to be poor in both countries, Italy and Poland display substantial differences in the current level of women's labour force participation (see Figure 3). Even larger differences emerge when past developments in women's economic activity are taken into account. Italy has always been described as a country with low levels of employment among women (e.g., Salvini 2004). Currently the employment rate of females aged 25-44 stands at $61 \%$, which is around 11 percentage points lower than the EU average. It is notable, however, that in the early 1970s the proportion of women employed was half as large, which points to a considerable increase. Single-earner, malebreadwinner couples are still seen as the most suitable environment for childbearing and childrearing in this country (Vignoli/Salvini 2008).

In contrast to Italy, the economic activity of women in Poland was already high in the 1960 s, when over $60 \%$ of women aged 25-44 participated in the labour force. By the end of the 1980 s, nearly $80 \%$ of Polish women were working. This high level involvement of women in economic activity was the result of the country's labour-intensive economy, low productivity and low wage policies; as well as the communist ideology that sought to achieve full employment. The conflict between paid work and childbearing was generally low at that time, due to the strong job guarantees, the right-to-a-job ideology, and public childcare provision. The situation changed dramatically after the centrally planned economy had been replaced by the capitalist system. Employment was no longer guaranteed, job security was undermined, public childcare deteriorated, and the importance of education in earning a good income and achieving personal success rose substantially. As a re- 
sult, a strong increase in work-family tensions was seen, and the employment rate of women aged 25 to 44 fell by around 12 percentage points at the beginning of the $1990 \mathrm{~s}$, and did not subsequently recover. Currently, Poland is among the countries with the lowest employment rates for women in Europe, with a rate that is only slightly higher than that of Italy (68.1\% versus $60.9 \%$ in 2008). Interestingly, young women in Poland have not responded to the growth in work-family tensions by reducing their economic activity, which remained high relative to Italy.

Figure 3: Labour force participation and employment rates (LFPR and EMPR) of Italian and Polish women aged 25-44, 1970-2007

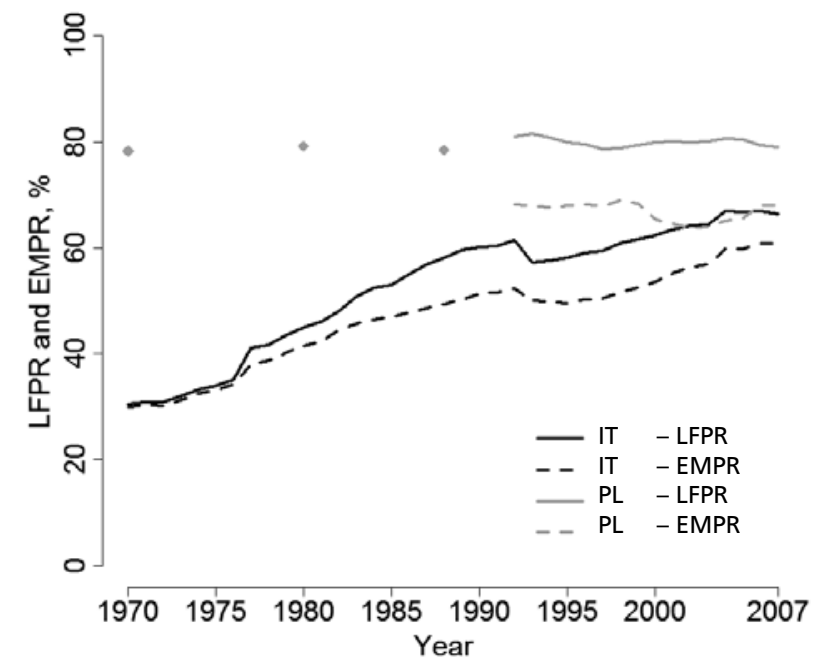

Note: In Poland all persons who were economically active before 1989 were employed, hence LFPR equals to EMPR.

Source: Italy 1970-2007 and Poland 1992-2007 - LFS data retrieved from the OECD Employment Database; Poland (1970-1988) - population census data retrieved from the ILO Laborsta (http://laborsta. ilo.org/)

\section{Employment around first birth in Italy and Poland: Empirical investigation}

\subsection{Data and sample selected}

In our empirical investigation, we made use of retrospective data stemming from the Household Multipurpose Survey Family and Social Subjects (FSS), corresponding to the Italian Generations and Gender Survey, and the Polish Employment, Family and Education Survey (EFES). The Italian survey was conducted by the Italian National Statistical Office (Istat) in November 2003 on a sample of about 24,000 households and 49,451 in- 
dividuals of all ages. The Polish survey was prepared at the Institute of Statistics and Demography of the Warsaw School of Economics, and was carried out in November and December 2006 on 3,000 women born 1966-1981.

We were interested in comparing Italy and Poland after the onset of fertility postponement. For this reason, we selected for Poland the cohorts born between 1970 and 1981. These women were aged eight to 19 in 1989, which means that most started their reproductive careers under the new political and economic conditions (see also Figure 1b). Using the same cohorts for Italy would mean following the Italian women for a period that is three years shorter than the period for Poland. For this reason, we chose for Italy cohorts born in the years 1967-1978. Selection of younger cohorts for Italy is additionally justified by the fact that fertility aging started in Italy earlier than in Poland (see Figures $1 \mathrm{a}$ and $1 \mathrm{~b}$ ). As a result, in both cases the analysed women were aged 25-36 at the time of the interview. Women who reported having twins at the first delivery were excluded from our samples. The Polish final sample includes 2,300 respondents (cohorts 1970-1981), while the Italian sample includes 4,238 respondents (cohorts 1967-1978).

\subsection{Employment before the first birth}

In the first step, we modelled the transition to the first birth. To this end, a piecewise linear intensity regression was applied. Each woman was observed from the age of 15 until first conception (measured seven months prior to birth) or the date of the interview. Our main explanatory covariates were women's employment status, as well as woman's educational attainment. Additionally, we standardised for the educational level of woman's parents. Unfortunately, we were not able to account for the employment situation of the partner due to lack of such information in the Polish dataset.

Women who had finished their education were classified into three groups: low, medium and high. The first category consists of women who completed only compulsory education (eight years in both countries), as well as those who continued with basic vocational education, which lasts three years in Italy and two years in Poland. The mediumeducated are those who completed at least four years of education at the upper-secondary level, as well as those who were enrolled in post-secondary, but non-tertiary, education. Women who received a bachelor's or a master's degree were classified as high-educated. Details on the method applied as well as full model estimates are available in the Appendix.

Our findings clearly demonstrate that, in Italy, the role of women's employment for childbearing is substantially different from that in Poland. While employed women in Italy are less likely to give birth to a first child, no significant differences between the employed and non-employed women are observed in Poland (see Table 2). Our findings therefore suggest that employed women in Italy are in general more likely to defer childbearing than their Polish counterparts. 
Table 2: First birth risk by employment status, Italy (cohorts 1967-1978) and Poland (cohorts 1970-1981)

\begin{tabular}{lcccc}
\hline & \multicolumn{2}{c}{ Italy } & \multicolumn{2}{c}{ Poland } \\
\cline { 2 - 5 } & $\begin{array}{c}\text { coeff. } \\
\text { (st.error) }\end{array}$ & relative risk & $\begin{array}{c}\text { coeff. } \\
\text { (st.error) }\end{array}$ & relative risk \\
\cline { 2 - 5 } Employment status & -0.42 & $0.66^{* *}$ & 0.07 & 1.08 \\
Employment & $(0.05)$ & $(0.06)$ & 1.08 \\
(ref=non-employment) & & &
\end{tabular}

Note: Significance level of coefficients: $*=10 \% ; * *=5 \% ; * * *=1 \%$. The results are standardised by calendar period, woman's age and educational attainment, as well as by women's and parents' education. Source: EFES 2006 for Poland (cohorts 1970-1981) \& FSS 2003 for Italy (cohorts 1967-1978), authors' calculations.

However, this general effect of employment on first birth risk hides differences in the role of employment between various educational groups (see Figures 4-5). After interacting educational level with women's employment status, we find that tertiary-educated women stand out from this general pattern. In contrast to low- and medium-educated women, they are more likely to conceive their first child if they have a paid job. This means that, for this group of women, finding a job is an important precondition for becoming a mother. This effect can be observed in both countries analysed, but it is more pronounced in Poland. In contrast to the high-educated, the medium- and the low-educated women in Italy are more likely to conceive their first child while out of employment. In Poland, no significant differences between employed and non-employed women in these two educational groups are observed.

Figure 4: First birth risk by employment status and educational attainment, Italy (cohorts 1967-1978). Piecewise linear intensity regression.

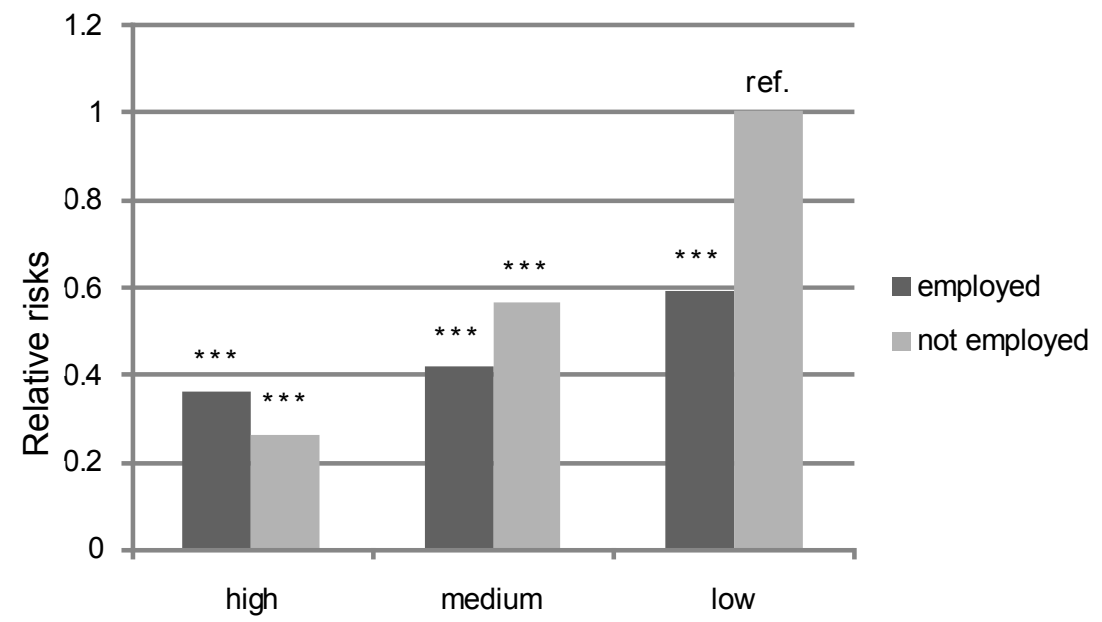

Note: Significance level of coefficients: $*=10 \% ; * *=5 \% ; * * *=1 \%$. The results are standardised by calendar period, woman's age and the educational level of the woman's parents.

Source: EFES 2006 for Poland (cohorts 1970-1981) \& FSS 2003 for Italy (cohorts 1967-1978), authors' calculations. 
Figure 5: First birth risk by employment status and educational attainment, Poland (cohorts 1970-1981). Piecewise linear intensity regression.

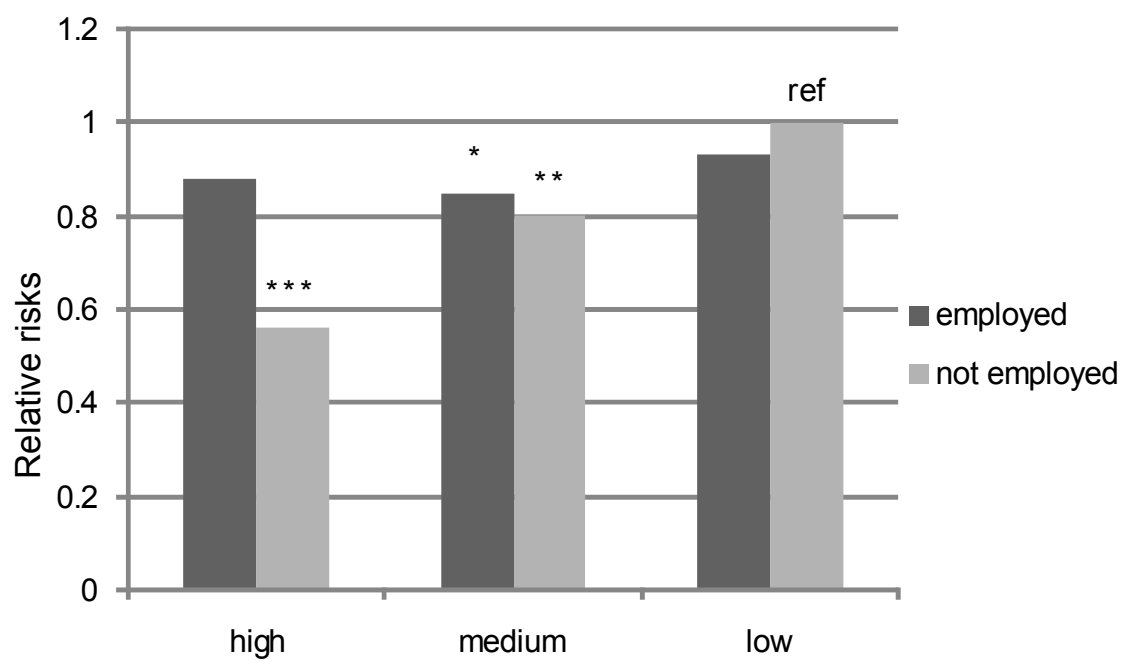

Note: Significance level of coefficients: $*=10 \% ; * *=5 \% ; * * *=1 \%$. The results are standardised by calendar period, woman's age and the educational level of the woman's parents.

Source: EFES 2006 for Poland (cohorts 1970-1981) \& FSS 2003 for Italy (cohorts 1967-1978), authors' calculations.

\subsection{Employment after first birth}

In the second step, we addressed the timing of women's employment (re-)entry after the first birth. The most straightforward solution to this problem would be to apply event history techniques in observing a woman from childbirth onwards. This approach was not appropriate in our case, as women on parental leave were coded as employed in the Italian dataset. Consequently, it was not possible for us to know the date when they decided to finish parental leave and to re-enter paid work. Given that mothers in Italy can be out of paid employment no longer than 11 months following birth without risking to lose their work contract, we decided to observe each woman starting with the first birthday of the first child. Descriptive event-history analysis techniques were used. Women were followed until the date of employment (re-)entry with censoring at second conception or the time of the interview, whichever came first. The resulting Kaplan-Meier estimates of survival curves were adjusted on the basis of the proportions of women at work one year after the first birth. Women who delivered more than one child at first birth were excluded from the analysis.

Although employment seems to hinder the transition to motherhood in Italy, but not in Poland, Italian mothers resume employment after their first birth more quickly than Polish women. Half of Italian mothers, but only one-third of Polish mothers, were working one year after the birth. This difference in re-entry rates can be due to differences in 
parental leave regulations. In fact, it turns out that the intensity of employment entry in Poland starts to exceed that of Italy after the child reaches 3.5 years of age, which is precisely the time when parental leave expires (see Figure 6).

Figure 6: Timing of the (re-)entry to employment after first birth. Kaplan-Meier survival curve estimates.

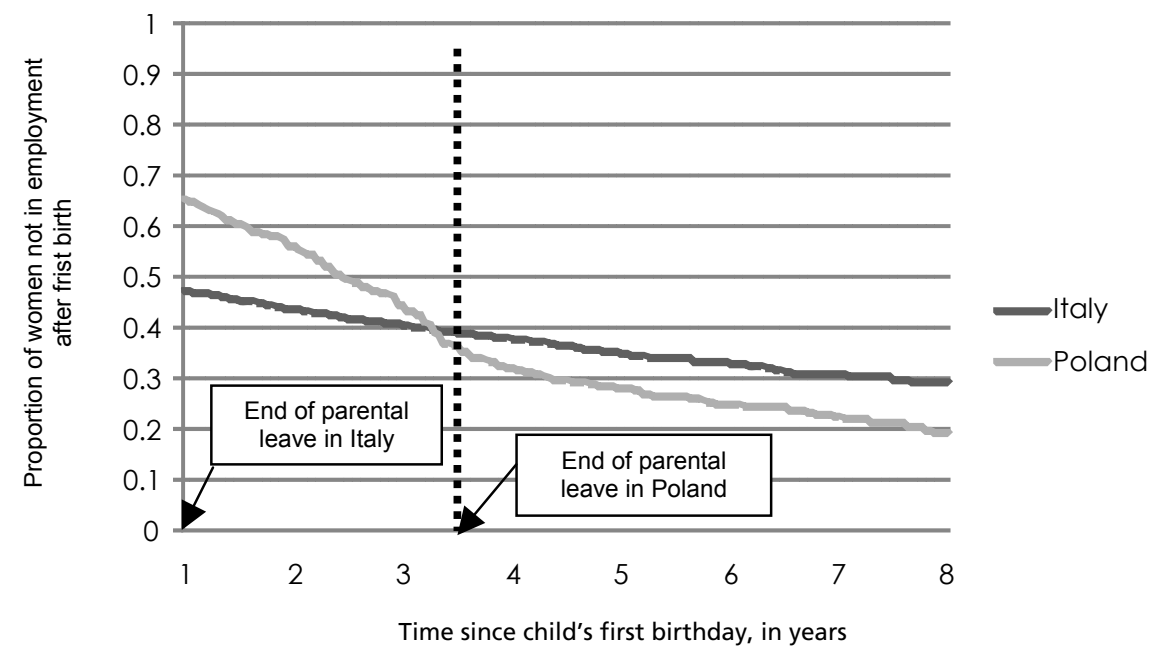

Source: EFES 2006 for Poland (cohorts 1970-1981) \& FSS 2003 for Italy (cohorts 1967-1978), authors' calculations.

It turns out, however, that the intensity of employment entry in Italy strongly depends on whether a woman was employed at least for some time before the first conception (see Figure 7), which points to a strong polarisation in behaviour. Almost $90 \%$ of Italian women who had some work experience entered employment one year after giving birth. Of those women who had never worked before they conceived, no more than $10 \%$ were employed one year after first birth, and only $20 \%$ were on the job three years later. Such a degree of strong polarisation was not observed in Poland, although women with some work experience were found to be more likely to enter paid work after childbirth than those who had never worked. 
Figure 7: Timing of the (re-)entry to employment after first birth, by women's work experience at first conception. Kaplan-Meier survival curve estimates.

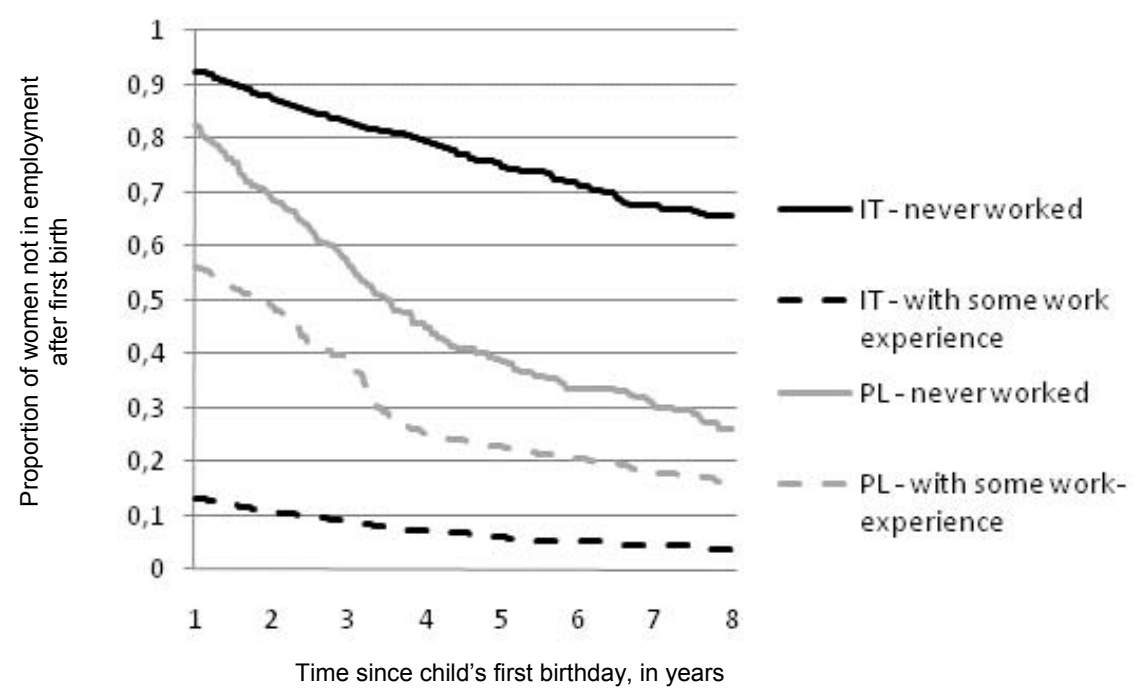

Source: EFES 2006 for Poland (cohorts 1970-1981) \& FSS 2003 for Italy (cohorts 1967-1978), authors' calculations.

Figure 8: Timing of the (re-)entry to employment after first birth by educational attainment. Kaplan-Meier survival curve estimates.

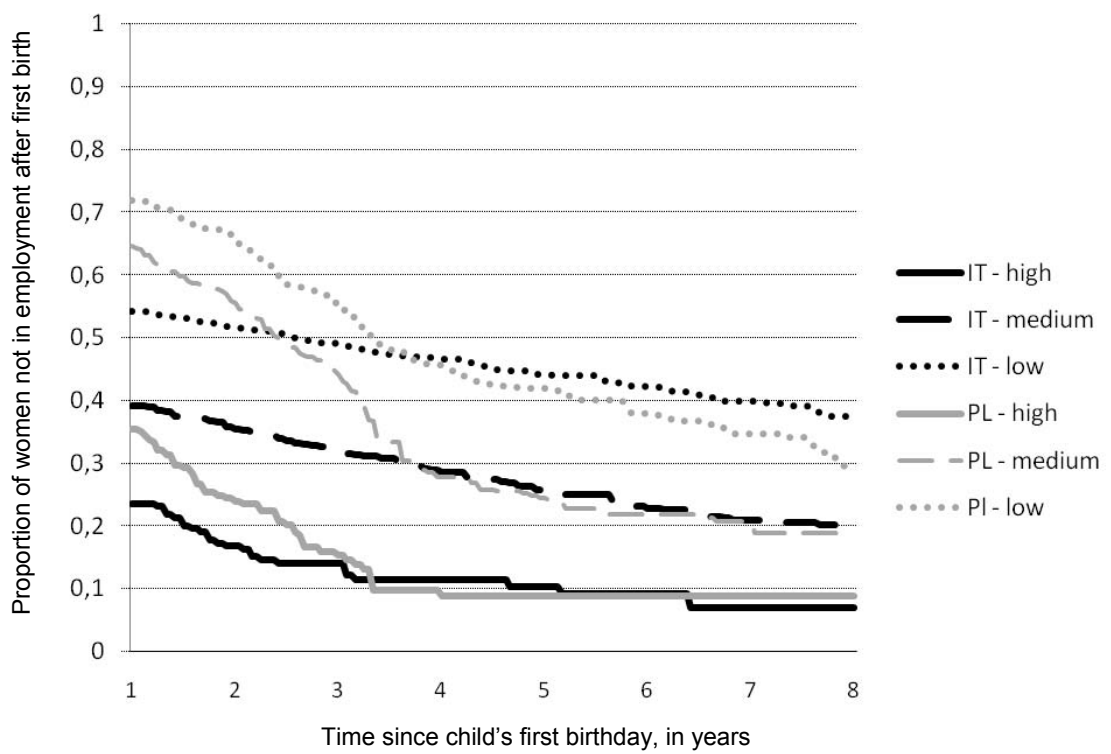

Source: EFES 2006 for Poland (cohorts 1970-1981) \& FSS 2003 for Italy (cohorts 1967-1978), authors' calculations. 
Disentangling the survival curves by women's educational attainment gives us a deeper insight into the cross-country differences in the patterns of employment entry after the first birth. It turns out (see Figure 8) that high-educated women in Poland are nearly as likely to enter employment as their Italian counterparts. This means that they attach more importance to the accumulation of on-the-job skills than lower-educated women. By contrast, the low- and medium-educated women in Poland seem to make use of the parental leave to a much larger extent, and to enter employment much later than similarly educated women in Italy. It is notable, however, that the proportion of mothers who entered employment after first birth in Poland following the expiry of the parental leave is similar to the proportion found for Italy.

\section{Concluding discussion}

In this paper, we looked at women's employment transitions around first birth in Italy and Poland. Although our research has some limitations due to the failure of controlling for the partner's employment situation, two important conclusions can be drawn from our study. First, we found important educational differentials in the way women's employment affects transition to motherhood, as well as in the intensity of employment entry after first birth, with tertiary-educated women displaying visibly different behaviour from low- and medium-educated women. Second, we also established clear cross-country differences in women's employment transitions around first birth, particularly for women with low and medium education. These differences were apparent despite the fact that one of the common features of these two countries is low public support for working parents, and the consequent tensions between work and family. They cannot be fully explained by differences in parental leave regulations in the two countries. The paper therefore demonstrates that conditions for combining work and family, although important, are not the only determinant of women's decisions regarding work and family. What also matters are other country-specific factors related to the cultural or economic frameworks, as well as women's attitudes regarding work and family. Below we briefly summarise and interpret these findings in greater detail.

We found that in both countries tertiary-educated women are more likely to conceive their first child if they are employed. It therefore seems that, for this group of women, finding a job is an important precondition for becoming a mother. These women also tend to (re-)enter employment quickly relative to low- and medium-educated women. The intensity of employment entry is only slightly higher in Italy than in Poland despite much longer leave entitlements in the latter country. Thus, it is clear that employment is an important life goal for tertiary-educated women in both countries, and that they seek to combine having a career with motherhood, despite the difficulties they are very likely to encounter.

For medium- and low-educated women, the findings were different. In Italy, employed women in this educational group were found to be less likely to enter motherhood. In Poland, employment does not seem to affect first birth intensity. Interestingly, low- and medium-educated women in Italy tend to (re-)enter employment more quickly after childbirth than in Poland. We attribute this finding to the differences in parental leave regula- 
tions, which allow mothers in Poland to stay at home around 2.5 years longer than in Italy without forfeiting their work contract. It is notable, however, that even the low and medium educated women in Poland do not wait till the end of the parental leave but gradually enter employment. When the child approaches the age of 3.5 years, the proportion of mothers in Poland who have entered work draws near to that of Italy. This means that Polish women are not more likely to abandon their jobs than Italian women; instead, they only make use of parts of their generous parental leave entitlements and try to enter employment afterwards, despite the possible depreciation of their human capital during the career break.

Additionally, our study revealed a strong polarisation pattern between working and non-working women in Italy: namely, we found that nearly all women who accumulated some work experience prior to their first conception swiftly re-entered paid work, often as early as one year after childbirth. By contrast, women who had never worked before first conception were more likely to remain out of the labour market after becoming mothers. These two distinct life-course trajectories seem to be predetermined by the decision whether to participate in the labour market at all, made after graduation at the latest. Such a polarisation pattern in employment entry after first birth in Italy has already been identified in previous research (see e.g., Saurel-Cubizolles et al. 1999; Gutiérrez-Domènech 2004), although only for the older cohorts. For Poland, the difference in the intensity of employment entry for women with some work experience and the intensity for women who have never worked is also visible, but it is far less pronounced than in Italy.

Overall, our results suggest that, despite similarly poor public support for working parents in Italy and Poland, paid employment and motherhood tend to be combined more often in the latter country. First, Polish women are more likely to give birth to their first child while employed than Italian women. Second, they do not make full use of the generous parental leave entitlements available, but gradually take up jobs before the leave expires. The most plausible explanation for these findings is that Polish women are much more attached to the labour force. This explanation is consistent with other research confirming the strong determination of Polish women to participate in the labour force (Kotowska/Sztanderska 2007; Matysiak/Steinmetz 2008). Since the parental leave system of Poland hardly offers any incentives to gather substantial work experience before first birth and to (re-)enter work before a second child is born, the sources of this strong determination of Polish women to participate in the labor force have to be searched elsewhere. Economic reasons are certainly one of the important factors. The average disposable income of Polish families is certainly far below the EU average while unemployment among men ranks among the highest across Europe. A study conducted by Matysiak and Mynarska (2010) shows, however, that, apart from financial aspects, employment is important for women also for other reasons. Being a housewife is generally not appreciated while participation in the labour market gives Polish women an opportunity to escape the limitation of domestic chores, to expand social contacts and personal development, and to do something more interesting and challenging than housework. This high priority of Polish women to participate in paid work might be a heritage of the socialist past, and its template of the full-time working woman. This ideal might have been transmitted from mothers to their daughters, and women might now be socially accepted as income providers. Future research is required to test this hypothesis as well as to better investigate reasons 
behind the differences in women's attachment to the labour market in Italy and Poland. Further studies could also look into how the employment entry after first birth affects the transition to a second child.

\section{Acknowledgement}

This research was conducted while Anna Matysiak and Daniele Vignoli were staying at the SUDA - Demography Unit, Department of Sociology, Stockholm University. The authors are grateful to Jan Hoem and the Max Planck Institute for Demographic Research in Rostock for providing financial support.

\section{References}

Dalla Zuanna, G. \& Micheli, G. A. (2004). Introduction - New perspectives in interpreting contemporary family and reproductive behaviour of Mediterranean Europe. In: G. Dalla Zuanna \& G. A. Micheli, (Eds), Strong family and low fertility: A paradox? New perspectives in interpreting contemporary family and reproductive behaviour. Springer (Series: European Studies of Population, 14), pp. 7-21.

De Rose, A., Racioppi, F. \& Zanatta, A. L. (2008). Italy: Delayed adaptation of social institutions to changes in family behaviour. Demographic Research, Special Collection, 7, 19, pp. 665-704.

Esping-Andersen, G. (1999). Social foundations of postindustrial economies. Oxford: Oxford University Press.

Eurostat (2005). Reconciliation between work and family life. Final report to the 2005 LFS ad hoc module. Luxembourg: Eurostat (Eurostat Methodologies and Working Papers). http://epp.eurostat.ec. europa.eu/cache/ITY_OFFPUB/KS-RA-07-011/EN/KS-RA-07-011-EN.PDF

Gustafsson, S. S. (2001). Optimal age at motherhood. Theoretical and empirical considerations on postponement of maternity in Europe. Journal of Population Economics, 14, pp. 225-247.

Gutiérrez-Domènech, M. (2004). Employment after motherhood: A European comparison. Labour Economics, 12, pp. 99-123.

Hantrais, L. (2005). Living as a family in Europe. In L. Hintrais, D. Philipov \& F. C. Billari (Eds), Policy implications of changing family formation. Strasbourg: Council of Europe Publishing, pp. 117-181.

Kotowska, I., Józwiak, J., Matysiak, A. \& Baranowska, A. (2008). Poland: Fertility decline as a response to profound societal and labour market changes? Demographic Research, Special Collection, 7, pp. 795-854.

Kreyenfeld, M. (2010). Uncertainties in female employment careers and the postponement of parenthood in Germany. European Sociological Review, 26 (3), pp. 351-366.

Kotowska, I. E. \& U. Sztanderska. (2007). Zmiany demograficzne a zmiany na rynku pracy w Polsce (Population changes and labour market developments in Poland). In: I. E. Kotowska, U. Sztanderska \& I. Wóycicka (Eds), Aktywność zawodowa i edukacyjna a obowiqzki rodzinne $w$ świetle badań empirycznych (Economic and educational activity versus family obligations). Warsaw: Scholar Publishing, pp. 13-46.

Lillard, L. A. (1993). Simultaneous equations for hazards: Marriage duration and fertility timing. Journal of Econometrics, 56, pp. 189-217.

Mai, R., Naderi, R. \& Schimany, P. (2008). Who should take care for them? Expectations placed on the welfare state and their influence on attitudes towards care for the elderly. In: C. Höhn, D. Avramov \& I. E. Kotowska (Eds), People, population change and policies: Lessons from the Population Policy Acceptance Study. Vol. 2: Demographic knowledge - gender - ageing. Springer (Series European Studies of Population, vol. 16/2), pp. 45-64. 
Matysiak, A. (2008). On the interdependencies between fertility and women's labour force participation. Warsaw: Warsaw School of Economics, Institute of Statistics and Demography (Doctoral thesis).

Matysiak, A. (2009a). Employment first, then childbearing: Women's strategy in post-socialist Poland. Population Studies, 63 (3), pp. 253-276.

Matysiak, A. (2009b). Is Poland really 'immune' to the spread of cohabitation? Demographic Research, 21, pp. 215-234 (Article 8).

Matysiak, A. \& Steinmetz, S. (2008). Finding their way? Female employment patterns in West Germany, East Germany, and Poland. European Sociological Review, 24 (3), pp. 331-345.

Matysiak, A., \& Vignoli, D. (2008). Fertility and women's employment: A meta-analysis. European Journal of Population, 24 (4), pp. 363-384.

Matysiak, A. \& Mynarska, M. (2010). Women's determination to combine childbearing and paid employment: How can a qualitative approach help us understand quantitative evidence? Warsaw: Institute of Statistics and Demography (ISD Working Paper No. 7).

Mencarini, L. \& Tanturri, M. L. (2006). High fertility or childlessness: Micro-level determinants of reproductive behaviour in Europe. Population, 4, pp. 389-416.

Muszyńska, M. (2007). Structural and cultural determinants of fertility in Europe. Warsaw: Warsaw School of Economics Publishing.

Neyer, G. \& Andersson, G. (2008). Consequences of family policies on childbearing behavior: Effects or artifacts? Population and Development Review, 34 (4), pp. 699-724.

Philipov, D. (2008). Family-related gender attitudes. The three dimensions: "Gender-role ideology", "consequences for the family, and "economic consequences". In: C. Höhn, D. Avramov \& I. E. Kotowska, (Eds), People, population change and policies: Lessons from the Population Policy Acceptance Study. Vol. 2: Demographic knowledge-gender-ageing. Springer (European Studies of Population, vol. 16/2), pp. 153-174.

Robert, P. \& Bukodi, E. E. (2005). The effects of the globalization process on the transition to adulthood in Hungary. In H.-P. Blossfeld, E. Klizing, M. Mills \& K. Kurz (Eds), Globalization, uncertainty and youth in society. London: Routledge, pp. 176-214.

Salvini, S. (2004). Low Italian fertility: The Bonaccia of Antilles?, Genus LX, 1, pp. 19-38.

Saurel-Cubizolles, M. J., Romito, P., Escribà-Aguir, V., Lelong, N., Pons, R. M. \& Ancel, P.-Y. (1999). Returning to work after childbirth in France, Italy, and Spain. European Sociological Review, 15, pp. 179-194.

Siemieńska, R. (1997). Wartości i postawy warunkujące obecność kobiet na rynku pracy (Values and attitudes determining women's labour supply). In: Siemieńska R. (Ed.), Wokót problemów zawodowego równouprawnienia kobiet i mężczyzn (On the gender equality in the labour market). Warsaw: Institute of Philosophy and Sociology, Polish Academy of Sciences.

Stankuniene, V. \& Maslauskaite, E. (2008). Family transformations in the post-communist countries: Attitudes toward changes and the ideational shift. In: C. Höhn, D. Avramov \& I. E. Kotowska (Eds), People, population change and policies: Lessons from the Population Policy Acceptance Study.Vol. 1: Family change. Springer (Series European Studies of Population, vol. 16/1), pp. 113-137.

Vignoli D. \& Salvini S. (2008). Couples' career, self-selection, and fertility in Italy. Proceedings of the XLIV Scientific Meeting of the Italian Statistical Society, University of Calabria, June 25-27, 2008.

Vignoli, D., \& Ferro, I. (2009). Rising marital disruption in Italy and its correlates. Demographic Research, 20, pp. 11-36.

Walker, J. R. (1995). The effect of public policies on recent Swedish fertility behaviour. Journal of Population Economics, 8, pp. 223-251.

Submitted on/Eingereicht am: 20.03.2010

Accepted on/Angenommen am: 08.10.2010 
Addresses of the authors/Anschrift der Autoren:

Dr. Anna Matysiak

Institute of Statistics and Demography

Warsaw School of Economics

Al. Niepodległości 164

02-554 Warszawa

Poland/Polen

E-Mail: amatys@sgh.waw.pl

Dr. Daniele Vignoli

Dipartimento di Statistica "G. Parenti"

Università degli Studi di Firenze

Viale GB Morgagni 59

50134 Firenze

Italy/Italien

E-Mail: vignoli@ds.unifi.it

\section{Appendix}

In the first step, a hazard regression was applied in order to model differentials in first birth risk by women's employment status. Among the control variables we included parents' education, calendar period and respondent's educational attainment interacted with time since leaving education. The baseline duration (namely the time from the age of 15 until first conception or the date of the interview, whichever comes first), calendar period and time since leaving education was specified on basis of a piecewise linear spline instead of a more common piecewise constant specification. Since splines are functions which are linear within an a priori defined interval, the rationale behind this choice is that with sufficient bend points this specification allows us to capture efficiently any loghazard pattern in the data (Lillard, 1993). In a second step, we interacted women's employment status with women's educational attainment. 
Table A1: Transition to first birth, basic model estimates

\begin{tabular}{|c|c|c|c|}
\hline & & & \\
\hline \multicolumn{4}{|c|}{ Age (spline) } \\
\hline & \multirow[t]{2}{*}{ constant } & $-8,01^{* * *}$ & $-5,95^{\star * *}$ \\
\hline & & $(0,28)$ & $(0,19)$ \\
\hline & \multirow[t]{2}{*}{$15-20$} & $0,42^{* * *}$ & $0,49^{* * *}$ \\
\hline & & $(0,05)$ & $(0,04)$ \\
\hline & \multirow[t]{2}{*}{$20-24$} & $0,20^{* \star *}$ & $0,14^{* * *}$ \\
\hline & & $(0,03)$ & $(0,03)$ \\
\hline & \multirow[t]{2}{*}{$24-28$} & $0,17^{\star \star *}$ & 0,03 \\
\hline & & $(0,03)$ & $(0,04)$ \\
\hline & \multirow[t]{2}{*}{$28-32$} & 0,04 & $-0,03$ \\
\hline & & $(0,03)$ & $(0,06)$ \\
\hline & \multirow[t]{2}{*}{$32-37$} & $-0,15^{\star *}$ & $-0,37^{*}$ \\
\hline & & $(0,07)$ & $(0,21)$ \\
\hline \multicolumn{4}{|c|}{ Calendar time } \\
\hline & \multirow[t]{2}{*}{ spline } & $-0,04^{* \star *}$ & $-0,04^{\star * *}$ \\
\hline & & $(0,01)$ & $(0,00)$ \\
\hline \multicolumn{4}{|c|}{ Educational attainment * time since leaving education (in years) } \\
\hline \multirow[t]{6}{*}{ high } & \multirow[t]{2}{*}{ constant } & $-0,04$ & $0,30^{*}$ \\
\hline & & $(0,34)$ & $(0,17)$ \\
\hline & \multirow[t]{2}{*}{$0-4$} & $0,45^{\star \star *}$ & $0,13^{\star *}$ \\
\hline & & $(0,10)$ & $(0,07)$ \\
\hline & \multirow[t]{2}{*}{$>4$} & $0,09^{*}$ & 0,00 \\
\hline & & $(0,05)$ & $(0,09)$ \\
\hline \multirow[t]{6}{*}{ medium } & \multirow[t]{2}{*}{ constant } & $0,61^{* *}$ & $1,08^{* * *}$ \\
\hline & & $(0,26)$ & $(0,11)$ \\
\hline & \multirow[t]{2}{*}{$0-4$} & $0,27^{* * *}$ & $-0,08^{* *}$ \\
\hline & & $(0,07)$ & $(0,04)$ \\
\hline & \multirow[t]{2}{*}{$>4$} & $0,05^{* *}$ & $-0,04$ \\
\hline & & $(0,02)$ & $(0,04)$ \\
\hline \multirow[t]{6}{*}{ Low } & \multirow[t]{2}{*}{ constant } & $1,75^{\star * *}$ & $1,51^{* * *}$ \\
\hline & & $(0,38)$ & $(0,16)$ \\
\hline & \multirow[t]{2}{*}{$0-2$} & $0,38^{* *}$ & $-0,06$ \\
\hline & & $(0,19)$ & $(0,09)$ \\
\hline & \multirow[t]{2}{*}{$>2$} & $-0,04^{* *}$ & $-0,12^{* * *}$ \\
\hline & & $(0,02)$ & $(0,02)$ \\
\hline \multicolumn{4}{|c|}{ Employment status } \\
\hline & \multirow[t]{2}{*}{ employed } & $-0,42^{* * *}$ & 0,07 \\
\hline & & $(0,05)$ & $(0,06)$ \\
\hline Father's & & & \\
\hline & low & $0,19^{* *}$ & $0,19^{* *}$ \\
\hline & & $(0,09)$ & $(0,07)$ \\
\hline Mother's & & & \\
\hline & low & 0,05 & $0,14^{*}$ \\
\hline & & $(0,10)$ & $(0,07)$ \\
\hline In-L & & $-12303,41$ & $-9445,48$ \\
\hline
\end{tabular}


Table A2: Transition to first birth, interaction model estimates

\begin{tabular}{|c|c|c|}
\hline & Italy & Poland \\
\hline \multicolumn{3}{|l|}{ Age (spline) } \\
\hline \multirow[t]{2}{*}{ constant } & $-5,64^{* \star *}$ & $-4,46^{* * *}$ \\
\hline & $(0,24)$ & $(0,21)$ \\
\hline \multirow[t]{2}{*}{$15-20$} & $0,38^{* * *}$ & $0,47^{* * *}$ \\
\hline & $(0,04)$ & $(0,04)$ \\
\hline \multirow[t]{2}{*}{$20-24$} & $0,21^{* \star *}$ & $0,04^{*}$ \\
\hline & $(0,03)$ & $(0,02)$ \\
\hline \multirow[t]{2}{*}{$24-28$} & $0,18^{* * *}$ & $-0,01$ \\
\hline & $(0,02)$ & $(0,03)$ \\
\hline \multirow[t]{2}{*}{$28-32$} & $0,06^{* *}$ & $-0,07$ \\
\hline & $(0,03)$ & $(0,06)$ \\
\hline \multirow[t]{2}{*}{$32-37$} & $-0,12^{*}$ & $-0,46^{* *}$ \\
\hline & $(0,07)$ & $(0,21)$ \\
\hline \multicolumn{3}{|l|}{ Calendar time } \\
\hline \multirow[t]{2}{*}{ spline } & $-0,05^{\star \star *}$ & $-0,04^{* \star *}$ \\
\hline & $(0,01)$ & $(0,08)$ \\
\hline \multicolumn{3}{|l|}{ Educational attainment } \\
\hline \multirow[t]{2}{*}{ High } & $-1,35^{\star * *}$ & $-0,57^{\star * \star}$ \\
\hline & $(0,17)$ & $(0,20)$ \\
\hline \multirow[t]{2}{*}{ medium } & $-0,57^{* * *}$ & $-0,22^{* *}$ \\
\hline & $(0,07)$ & $(0,10)$ \\
\hline \multirow[t]{2}{*}{ in education } & $-2,49^{* * *}$ & $-1,42^{\star \star \star}$ \\
\hline & $(0,14)$ & $(0,10)$ \\
\hline \multicolumn{3}{|l|}{ Employment status } \\
\hline \multirow[t]{2}{*}{ employed } & $-0,53^{* * *}$ & $-0,07$ \\
\hline & $(0,06)$ & $(0,08)$ \\
\hline \multicolumn{3}{|c|}{ Educational attainment * employment status } \\
\hline \multirow[t]{2}{*}{ high * employed } & $0,86^{* * *}$ & $0,51^{* *}$ \\
\hline & $(0,20)$ & $(0,22)$ \\
\hline \multirow[t]{2}{*}{ medium * employed } & $0,22^{* *}$ & 0,13 \\
\hline & $(0,10)$ & $(0,12)$ \\
\hline \multirow[t]{2}{*}{ in education * employed } & $1,46^{* * *}$ & $0,78^{* * *}$ \\
\hline & $(0,27)$ & $(0,15)$ \\
\hline \multicolumn{3}{|l|}{ Father's education } \\
\hline \multirow[t]{2}{*}{ Low } & $0,17^{*}$ & $0,18^{* *}$ \\
\hline & $(0,09)$ & $(0,07)$ \\
\hline \multicolumn{3}{|l|}{ Mother's education } \\
\hline \multirow[t]{2}{*}{ Low } & 0,04 & $0,13^{*}$ \\
\hline & $(0,10)$ & $(0,07)$ \\
\hline In-L & $-12353,7$ & $-9457,19$ \\
\hline
\end{tabular}

Source: EFES 2006 for Poland (cohorts 1970-1981) \& FSS 2003 for Italy (cohorts 1967-1978), authors' calculations. 